\section{A NEW OLIVANIC ACID DERIVATIVE PRODUCED BY \\ STREPTOMYCES OLIVACEUS: ISOLATION AND STRUCTURAL STUDIES}

\author{
S. J. Box, D. F. Corbett, K. G. Robins, \\ S. R. Spear and M. S. Verrall \\ Beecham Pharmaceuticals, Research Division, \\ Brockham Park, Betchworth, \\ Surrey RH3 7AJ, England
}

(Received for publication February 8, 1982)

During recent years, members of a novel class of $\beta$-lactam antibiotics containing a carbapenem nucleus have been reported ${ }^{1,2,3)}$. Studies with a culture of Streptomyces olivaceus CBS 349.80 capable of producing members of the olivanic acid series of carbapenem antibiotics, have demonstrated the presence of a new, but related antibiotic as a minor component which has been designated MM 27696.

Culture filtrate for extraction studies was produced by growing $S$. olivaceus CBS 349.80 in a fermentation medium composed of glucose $4 \%$, soybean flour $2 \%, \mathrm{CaCO}_{3} 0.04 \%, \mathrm{CoCl}_{2} \cdot 6 \mathrm{H}_{2} \mathrm{O}$ $0.0002 \%, \mathrm{Na}_{2} \mathrm{SO}_{4} 0.1 \%$, Pluronic L81 antifoam $(10 \%$ suspension in soybean oil) $0.2 \%(\mathrm{v} / \mathrm{v})$ in stainless steel fermenters. The procedure used for the extraction of MM 27696 is shown in Fig. 1. MM 27696 was assayed by $C_{18}$ reversed phase HPLC, using $5 \%$ acetonitrile in $0.05 \mathrm{M}$ ammonium phosphate buffer ( $\mathrm{pH} 4.7$ ) as eluant, and monitoring UV absorption at $300 \mathrm{~nm}$. As with previous compounds in this series ion pair extraction proved a valuable first stage in the isolation ${ }^{4}$. Using this procedure 3,800 liters of culture filtrate yielded approximately $15 \mathrm{mg}$ of MM 27696 in substantially pure form as its disodium salt.

The UV spectrum of MM 27696, having maxima at $306 \mathrm{~nm}$ and $228 \mathrm{~nm}$, was very similar to that of MM 13902. The results of thin-layer and paper chromatographic studies on both compounds are listed in Table 1, and show their similar ionic properties whilst demonstrating the greater lipophilicity of MM 27696. The results
Fig. 1. Isolation procedure for MM 27696.

Culture filtrate

extract with Aliquat 336 in dichloromethane

Dichloromethane extract

back extract with sodium nitrate solution

Sodium nitrate extract

adsorb impurities onto freshly precipitated $\mathrm{Al}(\mathrm{OH})_{3}$ and remove precipitate

Aqueous phase

| adsorb on Diaion HP20 elute with deionized water

Combine fractions containing MM 27696

chromatograph on QAE Sephadex A25 elute with gradient $0.1 \sim 0.7 \mathrm{M} \mathrm{NaCl}$ in $0.05 \mathrm{M}$ sodium phosphate buffer ( $\mathrm{pH} 7.0)$

Combine fractions containing MM 27696

adsorb on Diaion HP20 elute with deionized water

Combine fractions containing MM 27696

| concentrate by reverse osmosis

Concentrate

chromatograph on Diaion HP20 elute with deionized water

Combine fractions containing MM 27696

chromatograph on Biogel P2 elute with deionized water

Combine fractions containing MM 27696

chromatograph on Diaion HP20 elute with deionized water

Combine fractions containing MM 27696

chromatograph on reversed phase HPLC with $0.01 \mathrm{M}$ potassium phosphate buffer $(\mathrm{pH} 7.0)$

Combine fractions containing MM 27696

| desalt on Diaion HP20 elute with deionized water MM 27696

shown in Tables 2 and 3 demonstrate that MM 27696 has broad spectrum antibacterial activity and potent $\beta$-lactamase inhibitory activity.

The structure of MM 27696 was determined by conversion to its $p$-nitrobenzyl ester. A freezedried sample of MM 27696 disodium salt was treated with $p$-nitrobenzyl bromide in $N, N$ dimethylformamide and the resulting monoester was purified by column chromatography on silica gel. The IR spectrum ( $\nu_{\max }$. $(\mathrm{KBr}) 1760$, $1690,1627,1250$ and $1210 \mathrm{~cm}^{-1}$ ) and UV spectrum $\left(\lambda_{\max } \cdot\left(\mathrm{H}_{2} \mathrm{O}\right) 325,266\right.$ and $\left.220 \mathrm{~nm}\right)$ were characteristic of an olivanic acid ester with the 
Table 1. Paper and thin-layer chromatographic properties of MM 27696 and MM 13902.

\begin{tabular}{l|cc}
\hline \multirow{1}{*}{ System } & \multicolumn{2}{|c}{ Rf } \\
\cline { 2 - 3 } & MM 27696 & MM 13902 \\
\hline 1. TLC cellulose \\
$\begin{array}{l}\text { (Eastman-Kodak) } \\
n \text {-Propanol - water, 4: 1 }\end{array}$ & 0.83 & 0.74 \\
2. TLC DEAE cellulose \\
$\begin{array}{l}\text { 0.1 M NaCl in 0.05 M } \\
\text { pH 7.0 phosphate buffer }\end{array}$ & 0.18 & 0.17 \\
3. Paper (Whatman No. 1) \\
$\begin{array}{l}\text { Butanol - pyridine - } \\
\text { water, 1: } 1: 1\end{array}$
\end{tabular}

Table 2. Antibacterial activity of MM 27696 disodium salt.

\begin{tabular}{l|c}
\hline \multicolumn{1}{c|}{ Organism } & MIC $(\mu \mathrm{g} / \mathrm{ml})$ \\
\hline Enterobacter cloacae N1 & 0.2 \\
Escherichia coli 0111 & 0.8 \\
Klebsiella aerogenes A & 0.4 \\
Proteus mirabilis C977 & $<0.1$ \\
Pseudomonas aeruginosa A & 50 \\
Staphylococcus aureus Oxford & 0.4 \\
Streptococcus faecalis I & 12.5 \\
Streptococcus pneumoniae CN33 & $<0.1$ \\
\hline
\end{tabular}

Tests were carried out by serial dilution in nutrient broth by microtitre. Inoculum was prepared by dilution of an overnight broth culture to give the equivalent of $10^{6}$ cells $/ \mathrm{ml}$.
Table 3. $\beta$-Lactamase inhibitory activity of MM 27696 disodium salt.

\begin{tabular}{l|c}
\hline \multicolumn{1}{c|}{$\beta$-Lactamase } & $\begin{array}{l}\text { MM 27696 } \\
\left(\mathrm{I}_{50} \mu \mathrm{g} / \mathrm{ml}\right)\end{array}$ \\
\hline Enterobacter cloacae P99 & 0.002 \\
Klebsiella aerogenes E70 & 0.003 \\
E. coli JT4 & 0.01 \\
S. aureus Russell & 0.03
\end{tabular}

$\mathbf{I}_{50}$ values were determined with preincubation (5 minutes) of inhibitor with enzyme using nitrocefin $(250 \mu \mathrm{g} / \mathrm{ml})$ as substrate.

amidoethenylthio-substituent at $\mathrm{C}-3^{5}$. The NMR spectra of the $p$-nitrobenzyl ester revealed the structural difference between the new metabolite and MM 13902. The ${ }^{1} \mathrm{H}$ NMR spectrum (Table 4) was very similar to that of MM 13902, the most important difference being that the threeproton singlet due to the acetyl moiety in MM 13902 was absent and was replaced by a threeproton triplet at $\delta 1.07$ coupled to a two-proton quartet at $\delta 2.31(J=7.5 \mathrm{~Hz})$. This was consistent with the presence of a propionamido function in the C-3 side-chain of MM 27696 in place of the acetamido moiety possessed by MM 13902 and the other olivanic acids. The ${ }^{13} \mathrm{C}$ NMR spectrum (Table 5) was fully in accord with these conclusions, showing the presence of 21 carbon atoms and confirming the structure of the ester

Table 4. ${ }^{1} \mathrm{H}$ NMR spectrum of the mono-p-nitrobenzyl ester of MM 27696.

\begin{tabular}{c|cccl}
\hline$\delta\left(\right.$ DMF- $\left.d_{7}\right)$ & No. of $\mathrm{H}$ & Multiplicity & $J(\mathrm{~Hz})$ & \multicolumn{1}{c}{ Assignment } \\
\hline 1.07 & 3 & $\mathrm{t}$ & 7.5 & $\mathrm{CH}_{3} \mathrm{CH}_{2}$ \\
1.45 & 3 & $\mathrm{~d}$ & 6 & $\mathrm{CH}_{3} \mathrm{CH}$ \\
2.31 & 2 & $\mathrm{q}$ & 7.5 & $\mathrm{CH}_{2} \mathrm{CH}_{3}$ \\
3.03 & 1 & $\mathrm{dd}$ & $19.5,9.5$ & $4-\mathrm{CH}_{\mathrm{a}}$ \\
3.73 & 1 & $\mathrm{dd}$ & $5.5,11$ & $6-\mathrm{CH}$ \\
3.86 & 1 & $\mathrm{dd}$ & $19.5,8.5$ & $4-\mathrm{CH}_{\mathrm{b}}$ \\
4.29 & 1 & $\mathrm{~m}$ & & $5-\mathrm{CH}$ \\
4.56 & 1 & $\mathrm{~m}$ & & $\mathrm{CH}_{-} \mathrm{CH}_{3}$ \\
5.33 & 1 & $\mathrm{~d}$ & 13.5 & $\mathrm{CH}_{\mathrm{a}} \mathrm{C}_{6} \mathrm{H}_{4}-\mathrm{NO}_{2}$ \\
5.57 & 1 & $\mathrm{~d}$ & 13.5 & $\mathrm{CH}_{\mathrm{b}} \mathrm{C}_{6} \mathrm{H}_{4}-\mathrm{NO}_{2}$ \\
5.95 & 1 & $\mathrm{~d}$ & 14 & $=\mathrm{CHS}$ \\
7.23 & 1 & $\mathrm{dd}$ & 11,14 & $=\mathrm{CHN}$ \\
7.81 & 2 & $\mathrm{~d}$ & 9 & aromatic \\
8.28 & 2 & $\mathrm{~d}$ & 9 & protons \\
10.53 & 1 & $\mathrm{~d}$ & 11 & $\mathrm{NH}$ \\
\hline
\end{tabular}

Tetramethylsilane was employed as the internal standard. 
Table 5. ${ }^{13} \mathrm{C}$ NMR spectrum of the mono-p-nitrobenzyl ester of MM 27696.

\begin{tabular}{|c|c|c|c|}
\hline$\delta\left(\mathrm{DMF}-d_{7}\right)$ & Assignment & $\delta\left(\mathrm{DMF}-d_{i}\right)$ & Assignment \\
\hline 9.45 & $\mathrm{CH}_{3} \mathrm{CH}_{2}$ & 124.14 & Aromatic $\mathrm{C}-3^{\prime}, 5^{\prime}$ \\
\hline 20.35 & $\mathrm{CH}_{3} \mathrm{CH}$ & 129.03 & Aromatic $\mathrm{C}-2^{\prime}, 6^{\prime}$ \\
\hline 29.27 & $\mathrm{CH}_{2} \mathrm{CH}_{3}$ & 133.66 & $=\mathrm{CHN}$ \\
\hline 37.78 & $4-\mathrm{C}$ & 144.99 & Aromatic C-1' \\
\hline 54.53 & $6-\mathrm{C}$ & 148.21 & Aromatic C-4' \\
\hline 59.91 & $5-\mathrm{C}$ & 154.04 & $2-\mathrm{C}$ \\
\hline 65.30 & $C \mathrm{H}_{2} \mathrm{C}_{6} \mathrm{H}_{4}-\mathrm{NO}_{2}$ & 161.30 & $\mathrm{CO}_{2}$ \\
\hline 69.21 & $\mathrm{CHCH}_{3}$ & 171.97 & $\mathrm{COCH}_{2}$ \\
\hline 98.01 & $\mathrm{SCH}=$ & 177.76 & $\beta$-lactam CO \\
\hline 121.96 & $3-\mathrm{C}$ & & \\
\hline
\end{tabular}

Tetramethylsilane was employed as the internal standard.

Fig. 2. Structure of MM 27696, MM 13902 and their esters.

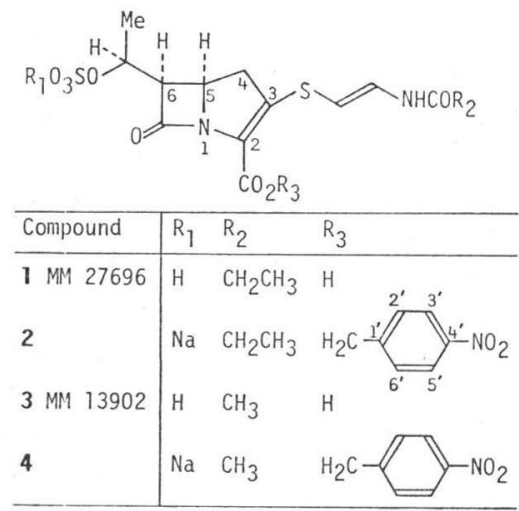

as that shown in Fig. 2, and hence the structure of MM 27696 shown in the same Fig. 2.

The discovery of MM 27696, an olivanic acid derivative with the acetyl function in the $\mathrm{C}-3$ side-chain replaced by a propionyl group, suggests the possibility of the natural occurrence of a range of such compounds with altered acyl sidechains.

\section{Acknowledgements}

The authors are indebted to Mr. G. HANSCOMB for large scale fermentations, Mr. M. BASKER for antibacterial data and Mr. C. READING for $\beta$-lactamase inhibition data. We also gratefully acknowledge the advice and support received from Dr. A. G. BRown and Mr. D. ButTerworth throughout this work.

\section{References}

1) Brown, A. G.: New naturally occurring $\beta$ lactam antibiotics and related compounds. $J$. Antimicrob. Chemother. 7: 15 48, 1981 and references therein.

2) Nakayama, M.; A. Iwasaki, S. Kimura, T. Mizoguchi, S. Tanabe, A. Murakami, I. Watanabe, M. Okuchi, H. Itoh, Y. Saino, F. Kobayashi \& T. MORI: Carpetimycins A and B, new $\beta$-lactam antibiotics. J. Antibiotics 33: $1388 \sim 1390,1980$

3) Tanaka, K.; J. Shoji, Y. Terui, N. Tsuji, E. Kondo, M. Mayama, Y. Kawamura, T. HatTORI, K. MATSUMOTO \& T. YoshidA: Asparenomycin A, a new carbapenem antibiotic. J. Antibiotics 34: 909 911, 1981

4) Hood, J. D.; S. J. Box \& M. S. Verrall: Olivanic acids, a family of $\beta$-lactam antibiotics with $\beta$-lactamase inhibitory properties produced by Streptomyces species. II. Isolation and characterisation of the olivanic acids MM 4550, MM 13902 and MM 17880 from Streptomyces olivaceus. J. Antibiotics 32: 295 304, 1979

5) Brown, A. G.; D. F. Corbett, A. J. Eglington \& T. T. HowARTH: Structure of olivanic acid derivatives MM 4550 and MM 13902; two new fused $\beta$-lactams isolated from Streptomyces olivaceus. J. Chem. Soc., Chem. Comm. 1977: $523 \sim 525,1977$ 